\title{
More than organic Sustainable agriculture resources
}

$\boldsymbol{S}_{\mathrm{u}}^{\mathrm{u}}$ ustainable agriculture is a broad concept, encompassing both a philosophy and a scientific practice, both consumers and farmers, both small- and large-scale operations, and both agricultural productivity and environmental health.

In post-World War II America, when industrialized agriculture seemed to be the way of the future, Rachel Carson's landmark Silent Spring (1962) made synthetic chemical pesticides and herbicides the subject of a national conversation and sparked new interest in the scientific study of sustainable agricultural methods. Although organically produced food has received much attention, especially at the consumer level, the sustainable agriculture movement expands well beyond that.

The United States Department of Agriculture (USDA) defines sustainable agriculture as a "way of practicing agriculture which seeks to optimize skills and technology to achieve long-term stability of the agricultural enterprise, environmental protection, and consumer safety." 1 This focus on long-term stability for both agriculture and the environment embeds agricultural practices and practitioners in the larger context of ecosystems and entire communities.

The University of California's Sustainable Agriculture Research and Education Program (SAREP) captures this context in its articulation of a "systems perspective" regarding sustainable agriculture: "The system is envisioned in its broadest sense, from the individual farm, to the local ecosystem, and to communities affected by this farming system both locally and globally ... A systems approach gives us the tools to explore the interconnections between farming and other aspects of our environment."

Although these definitions focus on farms, the sustainable agriculture movement also encompasses a lively "do-it-yourself" ethos, and many home gardeners, beekeepers, and small livestock enthusiasts are part of the sustainable agriculture movement on a smaller-scale. The National Gardening Association (NGA) determined that the number of U.S. households with organic gardens grew from 5 million in 2004 to 12 million in 2008, ${ }^{3}$ reflecting a growing awareness of the backyard garden's place in a larger ecosystem. Additionally, consumers are increasingly choosing organic food and beverages. The Organic Trade Association (OTA) reported that sales of organic food and beverages in the United States grew from \$1 billion in 1990 to $\$ 26.7$ billion in $2010 .{ }^{4}$

With this increased interest in sustainable agriculture and living, interest in academic programs offering education and training in these areas is also growing. Many colleges and universities offer undergraduate degrees or certificates in various aspects of sustainable agriculture, and, in 2002, Iowa State University became the first institution to offer graduate degrees in sustainable agriculture. ${ }^{5}$

One result of both the increased interest from various sectors of the population and the growing body of academic work in the field

Michele DeSilva is emerging technologies librarian at Central Oregon Community College's Barber Library, e-mail:mdesilva@cocc.edu

๑ 2012 Michele DeSilva 
is that the amount of high-quality information available to consumers, gardeners, and farmers is always increasing. The resources presented here highlight some of the best resources available to consumers, producers (of any scale), students, and researchers.

\section{Directories}

- Cooperative Extension System Offices. This site is a directory of the USDA Cooperative Extension offices. Cooperative Extension offices are in each state, are usually associated with land-grant universities, and are staffed by agriculture experts who provide the public with regionally appropriate information on farming, gardening, livestock, preserving food, and more. Although not specifically focused on sustainable agriculture, much of the information offered by Cooperative Extension offices is relevant to those interested in sustainable agriculture. Access: http://www. csrees.usda.gov/Extension/.

- Educational and Training Opportunities in Sustainable Agriculture. This site offers a comprehensive directory of educational institutions and other organizations offering credit or noncredit education and training in sustainable agriculture. The site includes U.S. and international listings. Access: http://www.nal.usda.gov/afsic/pubs /edtr/EDTR2009.shtml.

- Farming for Credit Directory. For students interested in studying sustainable agriculture and getting hands-on experience, this directory lists educational institutions in the United States and Canada that offer certificates or degrees in the various aspects of sustainable agriculture. Institutions are grouped by region. In addition to information on certificates and degrees at different institutions, this directory also lists information about campus farm operations. Access: http://www.rodaleinstitute. org/ffc_directory.

- Local Harvest. Local Harvest connects consumers with local farms, Community Supported Agriculture (CSA) organizations, farmers markets, meat processors, and more. The directory is searchable by zip code or by a map interface. Details in each listing include products available, hours, and seasons of operation. Access: http://www.localharvest.org/.

\section{ta LocalHarvest}

\section{Government agencies}

- Alternative Farming Systems Information Center (AFSIC). AFSIC serves as the USDA's portal to a wealth of information about sustainable agriculture in the United States. Consumers, producers, researchers, and students will find relevant and useful information on this site. Users can search the site or browse by topic. Access: http://afsic. nal.usda.gov/.

- Organic Agriculture. On this site, the Food and Agricultural Organization (FAO) of the United Nations offers information about sustainable agriculture internationally. Although the site title is Organic Farming, the scope extends beyond farming to include topics such as global food security, sustainable forestry, and sustainable fisheries. Users can view sustainable agriculture statistics and information by country or access a library of publications that address sustainable agriculture issues around the world. Access: http:// www.fao.org/organicag/oa-home/en/.

- Organic Farming-EUROPA. This site is the European Union's (EU) gateway to information about sustainable agriculture in the EU. It includes links to EU regulation and policy concerning organic products, rural development in the EU, and market statistics for organic products in the EU. It also offers consumers useful information about topics such as animal welfare, labeling standards, and genetically modified organisms (GMOs). Access: http://ec.europa.eu/agriculture /organic/home_en.

\section{Organizations and associations}

- The Kerr Center for Sustainable Agriculture. The Kerr Center for Sustainable Agriculture is a nonprofit, educational organization located in Oklahoma. Its site offers practical tips and information for the small farmer and the home gardener or livestock hobbyist alike. 
The site covers a wide diversity of topics, including growing cover crops, season extension, irrigation, composting, and vermicomposting (composting with worms). Under the "Resources and Information" menu heading, users will find both "Farming and Gardening (A to Z)," a collection of practical information arranged by subject, and "Food and Agriculture Issues," a collection of resources that examine some of the most heavily debated issues in sustainable agriculture. Access: http://www. kerrcenter.com/.

- National Sustainable Agricultural Information Service (ATTRA). ATTRA is a service of the National Center for Appropriate Technology (NCAT), a private nonprofit founded in 1976. Aimed primarily at practicing farmers, ranchers, and other agricultural professionals, ATTRA's site provides publications on a variety of practical topics, from tips for selling at farmer's markets to farm finances to sustainable soil management. Most of the publications are free. The site and publications are available in both English and Spanish. Access: https://attra.ncat.org/.

- Organic Trade Association (OTA). OTA is the "membership-based business association" for organic farmers in the United States and Canada. The OTA Web site, most of which is available to nonmembers, offers information about current advocacy campaigns, statistics on the organic market, and explanations of organic standards and labeling regulations. There is also a directory on the site that consumers can use to find organic producers and products. Access: http://www.ota.com/.

- Plants for a Future (PFAF). PFAF is a nonprofit organization based in England. The Web site offers a database of 7,000 plants that can be used for a variety of sustainable agriculture purposes, from eating to creating healthy wildlife habitat. Users can search the database by plant name or browse for plants by intended use. The site also offers tips on topics such as garden design and woodland gardening. Access: http://www.pfaf.org/.

- Rodale Institute. The Rodale Institute, founded in 1947 in rural Pennsylvania, is one of the United State's oldest organic farming

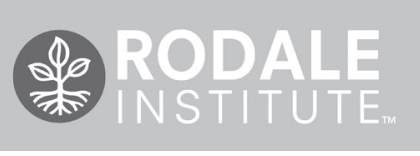

organizations. Its Web site promotes organic farming, reports on results of research on its working farm, and offers information and resources to farmers and consumers on the benefits of sustainable agriculture. Access: http://www.rodaleinstitute.org/.

- Seed Savers Exchange. Seed Savers is a nonprofit organization that encourages the preservation of heirloom seed varieties and facilitates an heirloom seed exchange through its network of members. The Web site is a good source for finding both heirloom seeds and information on saving seeds. Access: http:// www.seedsavers.org/.

- Slow Food USA. Slow Food USA is "part of a global, grassroots organization" that supports sustainable food systems for people all over the world. The site offers access to information about current food and agriculture issues in the United States and beyond. Access: http://slowfoodusa.org/.

- Sustainable Agriculture Education Association (SAEA). SAEA focuses on promoting best practices in the curricula, research, and teaching of sustainable education. The organization is open to both educators and students. The Web site also offers access to

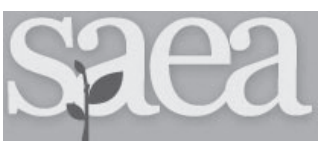
the Sustainable Agriculture Education Materials (SAEM) database, a collection of reusable education resources for teaching sustainable agriculture. Access: http:// sustainableaged.org/.

\section{Publications and media}

- Motber Eartb News. This online site of the popular magazine covers a wide variety of topics of interest to those interested in sustainable agriculture, including organic gardening, small livestock, preserving food, saving seeds, renewable energy, and many current issues in

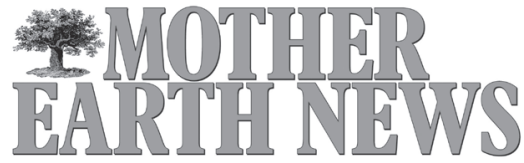


the sustainable agriculture field. Access: http:// www.motherearthnews.com/.

- The New York Times Urban Agriculture News. Urban agriculture is gaining attention as a way to increase the sustainability of the world's food supply. This site collects articles that have appeared in The New York Times about the topic. Access: http://topics.nytimes.com/top/reference/timestopics /subjects/a/agriculture/urban_agriculture /index.html.

- Organic Gardening. Organic Gardening was first published in 1942 by the Rodale Institute (see previous page). Its Web site is an excellent resource for those interested in practical information on organic gardening at home. The "Learn and Grow" section of the site offers access to information by topic or by an A to $\mathrm{Z}$ index. Access: http://www. organicgardening.com/.

- Urban Farm Online. The online outpost of a relatively new print magazine, Urban Farm provides useful tips to city- or suburbdwellers who want to grow food or raise animals in small spaces. Access: http://www. urbanfarmonline.com/.

- You Bet Your Garden. This weekly public radio show is produced by WHYY-FM in Philadelphia and described as "an hour of chemical-free horticultural hijinks." Each episode features several topics of interest to the home gardener and call-in questions from listeners all over the country. The Web site allows users to listen to the current and archived episodes or explore an A to $\mathrm{Z}$ index of past questions and answers. Access: http://www. whyy.org/91FM/ybyg/index.html.

\section{Research}

- AGRICOLA. The USDA's National Agricultural Library (NAL) catalog lets researchers and students find freely available electronic resources, such as government-funded research and reports. Users can also search the library's print collection and access-restricted electronic resources. Access: http://agricola.nal.usda.gov/.

- Leopold Center for Sustainable Agriculture. Founded in 1987 and located at Iowa State University, the Leopold Center is renowned for funding significant research on sustainable agriculture. Although much of its research focuses specifically on Iowa, it is a resource of which any student or researcher interested in sustainable agriculture should be aware. Access: http://www.leopold.iastate. edu/.

- Organic Farming Research Foundation (OFRF). The Organic Farming Research Foundation gives grants to farmers and researchers and conducts its own research. It also has a policy arm, the Organic Farmers Action Network (OFAN), which advocates for
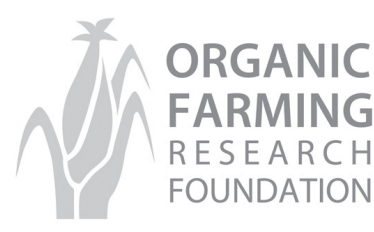
organic farming causes in Congress. Additionally, OFRF sponsors the Scien-

tific Congress on Organic Agricultural Research (SCOAR), a "network of farmers, researchers and extensionists who are interested in organic farming research and information-exchange." Access: http://ofrf.org/.

- Organic Roots Collection. The Organic Roots Collection is a digital archive hosted at the National Agricultural Library. The archive contains agricultural research and documents published prior to 1942, before synthetic chemicals were commonly used in agriculture. Access: http://organicroots.nal.usda.gov/.

- Sustainable Agriculture, Research, and Education (SARE) Learning Center. Funded by Congress in 1988, SARE's mission is to support research of sustainable agriculture and distribute the results of that research to the public. The SARE Learning Center provides useful fact sheets, bulletins, online courses, and its catalog of handbooks. Handbooks are for purchase, but most of the other resources are free. Access: http://www. sare.org/Learning-Center.

\section{Notes}

1. M. V. Gold, (2007), "Sustainable Agriculture: Definitions and Terms," Special Reference

(continues on page 415) 
of home design shows has made consumers, including students, more knowledgeable about, and aware of, good design. A clean and uncluttered appearance sends a powerful message that the library is relevant by today's standards.

"When you take control of your message and of how you want to be perceived by otherpeople, it's empowering. "3

Creating a brand is a powerful and effective way to establish a predefined image of your library in the minds of its users. There are companies that specialize in creating visual identities for corporations, but there are simple steps a library can take to develop a targeted and consistent identity in its users' minds. Develop a logo or tagline that reflects the mission of the library and differentiates it from other resources within and outside the university. Use your library's logo in a manner that is consistent with its vision. A library tagline on a USB drive is logical, but a logo on a Frisbee can create a disconnect between the object and the library's brand. Create a style manual that clearly states the font, type size, and color that are to be used in all library materials so that everything, from class handouts to annual reports, visually represents the library in the same manner.

"Fabulousity is not just a way of life: it's a state being. . . . More than anything, you are fabulous if you treat people with respect and encourage them to develop their own fabulous qualities. ${ }^{\text {"t }}$

Great design, clear signage, and a focused identity can only do so much to make a library

("More than organic," cont. from page 407)

Brief Series no. SRB 99-02 (Beltsville, MD: National Agricultural Library), www.nal.usda. gov/afsic/pubs/terms/srb9902.shtml (accessed May 21, 2012).

2. G. Feenstra (n.d.), "What is Sustainable Agriculture?" (Davis, CA: Agricultural Sustainability Institute, UC Davis), www.sarep.ucdavis. edu/sarep/about/def (accessed May 21, 2012).

3. B. Butterfield (n.d.), "Garden Market Research" (South Burlington, VT: National user's visit satisfactory. If you are not providing timely and respectful service, none of the hard work you have done to improve your library's appearance will make a difference.

It is easy to dismiss concerns about appearances as frivolous, but we make decisions based on how something or someone looks on a daily basis. Does this street look safe to walk down? Does this salesperson look like she will be helpful? This restaurant looks filthy; should we eat here? Some decisions may be lifesaving; others may just enhance an experience.

Academic libraries provide an important service to their communities. Creating a safe and clean environment that is easy to navigate with well-designed spaces and clear and concise signage is something that can be done on a small or large budget. Paying attention to your library's appearance can go far to enhance a patron's experience.

\section{Notes}

1. Clinton Kelly, Freakin' Fabulous (New York: Simon Spotlight Entertainment, 2008), 3.

2. Devny Renner, "Clinton Kelly Interview," BlogHer: Life Well Said, 1 March 2011, www.blogher.com/tlcs-what-not -wear-ambushes-parenting-dummies-dc-and -clinton-kelly-agrees-his-first-social-media -int?page $=0,1$.

3. Erin Casey, "1-on-1: Confidence Never Goes Out of Fashion," Success Magazine, 2011, www.successmagazine.com/1on1 -clinton-kelly/PARAMS/article/1407 /channel/22.

4. Kelly, 239. n

Gardening Association, www.gardenresearch. com/home?q=show\&id=2896, (accessed May 21, 2012).

4. "Industry Statistics and Projected Growth,” (2011) (Battleboro, VT: Organic Trade Association) www.ota.com/organic /mt/business.html (accessed May 21, 2012).

5. "Questions and Answers-Graduate Program in Sustainable Agriculture" (2010). (Ames, IA: Iowa State University, www.sust. ag.iastate.edu/gpsa/qanda.html (accessed May 21, 2012). $\boldsymbol{n}$ 